\title{
コンクリートダムの総合品質管理システム
}

西 岡 真 帆*

1.はじめに

コンクリートダムの施工においては，現地プラントで のコンクリート製造や，有害なひび割れを抑制するため の温度計測管理が必要となり，一般的なコンクリート工 事と比較して，さらに多くの品質管理が必要となる。

従来, これらの品質管理は, 担当者ごとに品質管理デー 夕や施工管理データの記録を行い，温度計測管理につい ては個々のシステムを構築しながら対応してきているが, 総合的な判断を行う場合は，各種データの集約が容易に は行えないという課題があり，すべての品質管理デー夕 や施工管理データが一元管理されることが望まれていた。

このような背景を受けて，高流動コンクリートの品質 管理を目的とした従来システム ${ }^{1)}$ と，一般的なコンクリー 卜工事を対象として実用化されていたシステム ${ }^{2)}$ の機能 を拡張することにより，コンクリートダムを対象とした 品質管理システムを開発した。

本稿では，コンクリートダムの総合品質管理システム の概要と, 本システムを適用した施工現場での運用状況
を報告する。

\section{2. システムの概要と特徵}

コンクリートダムの総合品質管理システムは，身近な ツールであるパソコン，携帯電話とインターネットによ り構成されるものであり，コンクリートダム工事の品質 管理業務を総合的に支援することを目的としている。

具体的には，製造担当者や，施工担当者が現場で得た コンクリートの品質データや写真データなどを，パソコ ンや携帯電話からインターネット上のサーバーへ直接送 信することにより，品質管理記録をリアルタイムで行え ることと，コンクリートの温度計測管理のモニタリング が可能であることが最大の特徵である。サーバーとして， 外部の $\mathrm{ASP}^{* \mathrm{i}}$ を利用することで，インターネットを通 じて関係者全員が同じ情報を共有できるようにした。パ ソコンから入力されたデータはサーバー内で自動的に記 録保存され，表計算ソフトで作成した発注者への提出書 類や施工記録などの帳票を印刷，保存することができる ようにした。図-1にシシステムの概念図を示す。

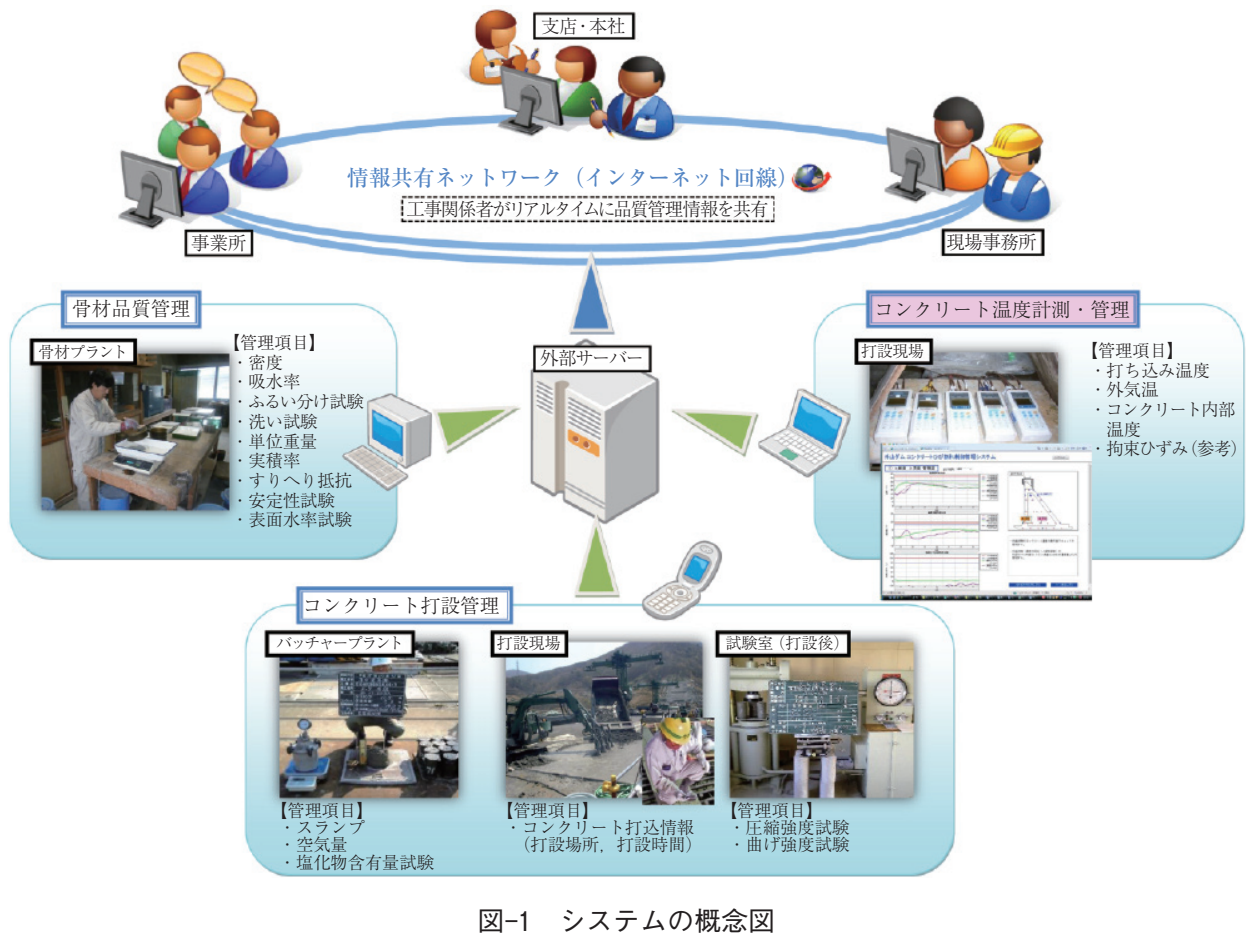

* にしおか・まほ/清水建設(侏) 土木技術本部 基盤技術部 課長（正 会員） *i Application Service Provider の略で，ビジネス用のアプリケーショ ン・ソフトをインターネット回線を通じて利用するサービス 
本システムの主な特徵は，以下の 3 点である。

（1）品質管理情報の共有化で, 工事管理の精度向上 と品質管理情報の信頼性・透明性を図る

本システムは, 工事発注者, 現場担当者および支店・ 本社の技術スタッフなど工事関係者全員で品質管理情報 をリアルタイムに共有化することが可能である。例え ば，コンクリートの温度計測管理状況を，工事関係者な ら誰でもリアルタイムに，また現場から離れた場所から でも把握できるため, 品質上の不具合を未然に防止でき, 品質管理の精度が大幅に向上することが期待できる。ま た，品質管理情報の信頼性や透明性という点でも，一段
と優れていると考えられる。

（2） 温度計測管理のモニタリングが可能

従来の温度計測管理はシステムをインストールしたパ ソコンでのモニタリングが主流であり，特定の工事関係 者しか状況を把握できないという課題を, インターネッ 卜経由のシステムとすることで，すべての工事関係者が リアルタイムに状況を把握できることを可能とした。

（３）データ入力や帳票作成作業などの情報処理業務 を省力化

本システムは，各担当者がパソコンから直接データを 入力し，サーバー内で自動的にデータが処理されて，帳

表-1 出力帳票一覧表

\begin{tabular}{|c|c|c|c|c|}
\hline & 検査場所 & 検査項目 & 個別帳票 & 一覽表‧管理図 \\
\hline \multirow{4}{*}{$\begin{array}{l}\text { 骨 } \\
\text { 材 } \\
\text { 管 } \\
\text { 理 }\end{array}$} & \multirow{4}{*}{$\begin{array}{l}\text { 骨材 } \\
\text { プラント }\end{array}$} & 密度 & \multirow{2}{*}{$\begin{array}{l}\text { 『細骨材の密度および吸水率試験表』 } \\
\text { 『粗骨材の密度および吸水率試験表』 }\end{array}$} & \multirow{2}{*}{ 『骨材の表乾密度 · 絶乾密度 · 吸水率一覧表』 } \\
\hline & & 吸水率 & & \\
\hline & & 粒度 & $\begin{array}{l}\text { 『細骨材のふるい分け試験』 } \\
\text { 『骨材のふるい分け試験表』 }\end{array}$ & $\begin{array}{l}\text { 『細骨材のふるい分け試験一覧表』 } \\
\text { 『粗骨材のふるい分け試験一覧表』 } \\
\text { 『細骨材 (砕砂) 粒度分布』 }\end{array}$ \\
\hline & & 表面水率 & $\begin{array}{l}\text { 『細骨材の表面水率試験』 } \\
\text { 『骨材の含水率試験 } \\
\text { および含水率に基づく表面水率の試験』 } \\
\text { 『打設管理日報』 }\end{array}$ & 『表面水率試験結果一覧表』 \\
\hline \multirow{12}{*}{$\begin{array}{l}\text { 打 } \\
\text { 設 } \\
\text { 管 } \\
\text { 理 }\end{array}$} & \multirow{7}{*}{$\begin{array}{l}\text { 試 験 室 } \\
\text { (製造時) }\end{array}$} & スランプ & \multirow{6}{*}{ 『打設管理日報』 } & \multirow{8}{*}{$\begin{array}{l}\text { 『スランプ·空気量 } \cdot \text { 単位容積質量 } \\
\text { ·温度試験結果一覧表』 } \\
\text { 『工程能力図 } \\
\text { (スランプ・空気量 } \cdot \text { 単位容積重量 }) 』\end{array}$} \\
\hline & & 空気量 & & \\
\hline & & 練上り温度 & & \\
\hline & & 気温 & & \\
\hline & & 水温 & & \\
\hline & & 単位容積重量 & & \\
\hline & & 塩化物含有量 & $\begin{array}{l}\text { 『打設管理日報』 } \\
\text { 『コンクリート中の塩化物含有量測定記録』 }\end{array}$ & \\
\hline & \multirow{2}{*}{ 打設現場 } & 打込み温度 & \multirow{2}{*}{ 『打設管理日報』 } & \\
\hline & & トレーサビリティー & & 『打設実績表』 \\
\hline & \multirow{3}{*}{$\begin{array}{l}\text { 試 験 室 } \\
\text { (打設後) }\end{array}$} & 圧縮強度 & - & $\begin{array}{l}\text { 『圧縮強度試験結果一覧表』 } \\
\text { 『X- } R_{s}-R_{m} \text { 管理図』 }\end{array}$ \\
\hline & & 割裂引張強度 & \multirow{2}{*}{-} & \multirow{2}{*}{$\begin{array}{l}\text { 『割裂引張強度試験 } \\
\text { ·単位容積質量試験結果一覧表』 }\end{array}$} \\
\hline & & 単位容積重量 & & \\
\hline
\end{tabular}

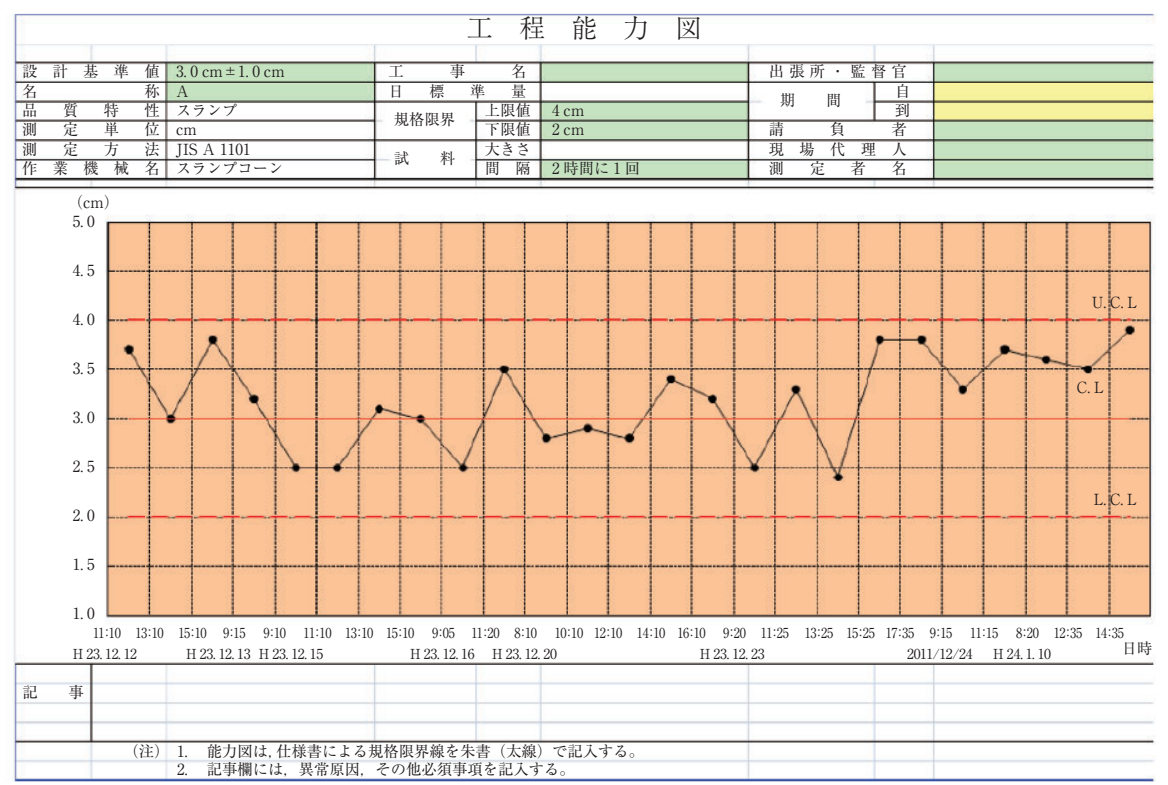

図-2 工程能力図の一例（スランプ試験） 
票を作成するものである。1 回の入力作業で, 種々の帳 票に同じデータが反映されることから，情報処理に要す る手間や時間を大幅に軽減できると考えられる。

本システムのメニューは, 骨材管理, 打設管理, 温度 計測管理に分かれており，トップメニューからすべての 管理データにアクセス可能とした。表-1にメニューご との検査項目別に出力帳票の一覧を, 図-2に工程能力 図の一例を示す。

各メニューの具体的な内容について以降に示す。

\section{3. 骨材管 理}

コンクリートダム工事では, 現地プラントでコンクリー トの製造を行うため，骨材の受入れ検査が必須である。 骨材の品質を確保するための試験は, 試験頻度, 試験項 目とも多いことから，膨大なデータの処理が発生する。

骨材管理メニューでは, 細骨材, 粗骨材の種別ごとに, 密度·吸水率, ふるい分け, 表面水率の 3 種類について, 品質管理データを記録できる方式とした。WEB 画面か ら入力したデータが, 直接サーバーに保存されるため, 常に最新のデータが反映される仕組みである。個別の帳
票はいずれも JIS に準拠した様式としたほか，表計算ソ フトで一覧表の出力も可能とした。

4. 打設管理

コンクリートダム工事では，ほぼ毎日コンクリートの 打込みを行い，同一日に複数の配合を使用することが一 般的である。

打設管理メニューでは，打設日ごとのフレッシュ性状 （スランプ・空気量・温度など）と硬化性状（圧縮強度 単位容積重量など）について，品質管理データを記録で きる方式とした。図-3にコンクリート検査の WEB 画面 を示す。

なお、コンクリートダムの施工管理においては，打达 み箇所でのコンクリート温度の規制が設けられる場合も あることから, 打込み温度と外気温との関係が簡単に把 握できるようなグラフ作成機能も追加して，製造管理お よび施工管理に迅速にフィードバックできるような工夫 もしている。写真-1に打込み温度測定状況を, 図-4に 打設温度グラフを示す。

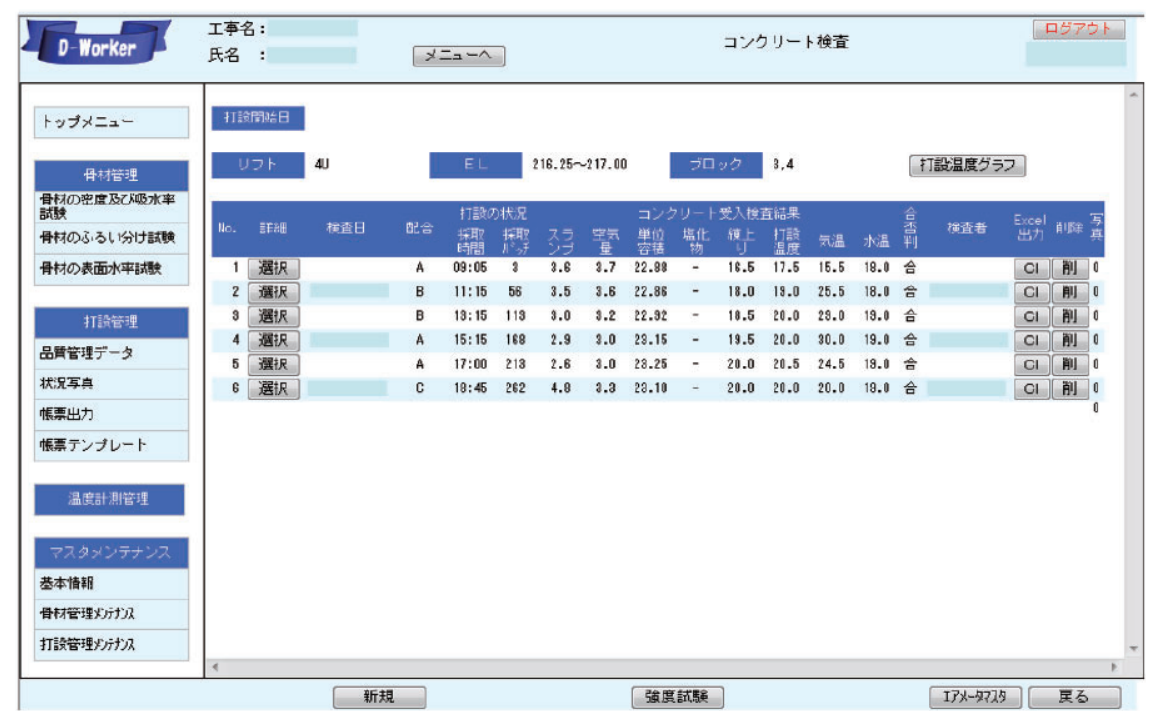

図-3 打設管理［コンクリート検査］

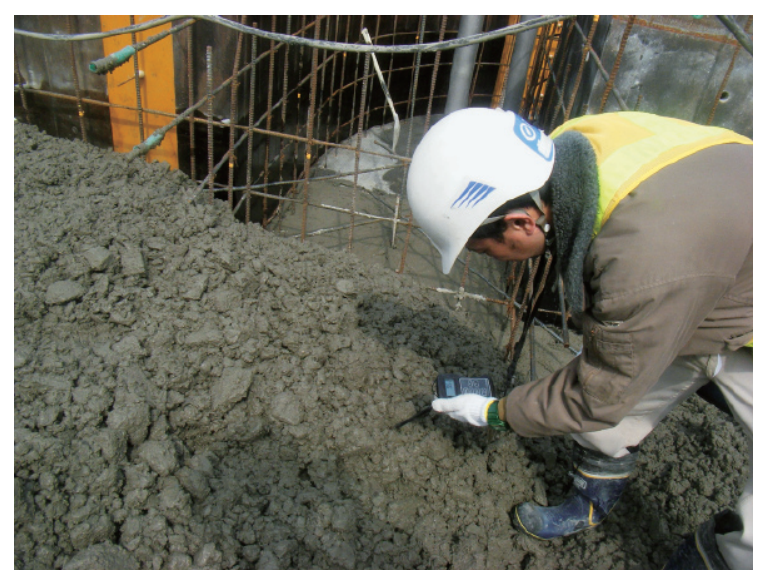

写真-1 打込み温度測定状況

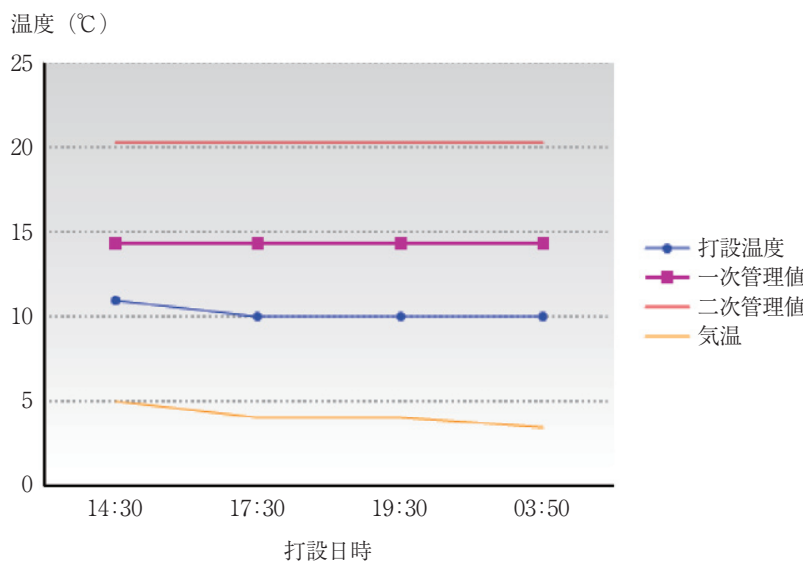

図-4 打設管理［打設温度グラフ］ 


\section{5. 温度計測管理}

ダムはマッシブなコンクリート構造物であり, セメン トの水和熱や気温の季節変化に起因した温度ひび割れが 発生する可能性がある。特に，夏季に打設したリフトの 上下流面が冬季に冷却され，ダムの内部温度と表面温度 との温度差によるひび割れが発生する可能性がある。こ のため, コンクリートダム工事では，コンクリート内に 計測計器を設置し，コンクリート温度や，内部と表面の 温度差，拘束ひずみなどを管理することによりひび割れ 抑制を行うことが通常行われている。

管理值は，事前に温度応力解析により設定し，施工の進 渉に合わせて，常に管理值との比較を行いながら，養生方 法や養生期間，打込み温度などを管理する必要が生じる。

従来, 温度計測管理システムは, 個別のパソコンや,
限られたネットワーク内で用いられてきたが、本システ ムに組込むことにより，インターネット経由ですべての 工事関係者が情報を共有することが可能となった。

図-5にメイン画面を示す。メイン画面では，計測断 面を対象として, 計測計器の設置位置と, 工事の進渉状 況が一目で把握できるような工夫をした。打設済みのリ フトは，打設管理データとリンクすることにより着色表 示している。

図-6に温度計測結果画面を示す。計測計器位置の枠 内には,リアルタイムの計測データを表示している。背 面のコンター図は，事前に実施した温度応力解析結果で ある。事前解析結果と, 実測值を比較することにより, 事前計画の妥当性を即座に把握すること, 異常時には迅 速に対応することが可能だと考えられる。画面右側には, 管理項目一覧を示し，項目を選択することにより個別の

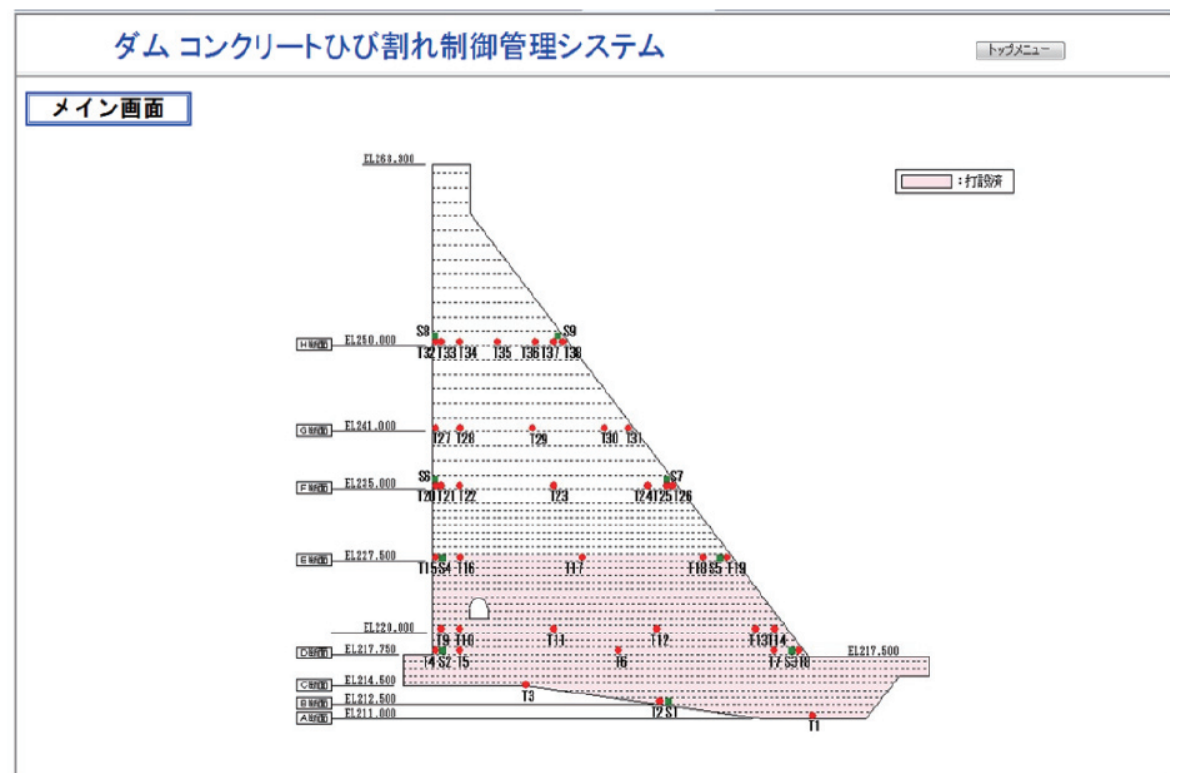

図-5 温度計測管理 [メイン画面 $]$

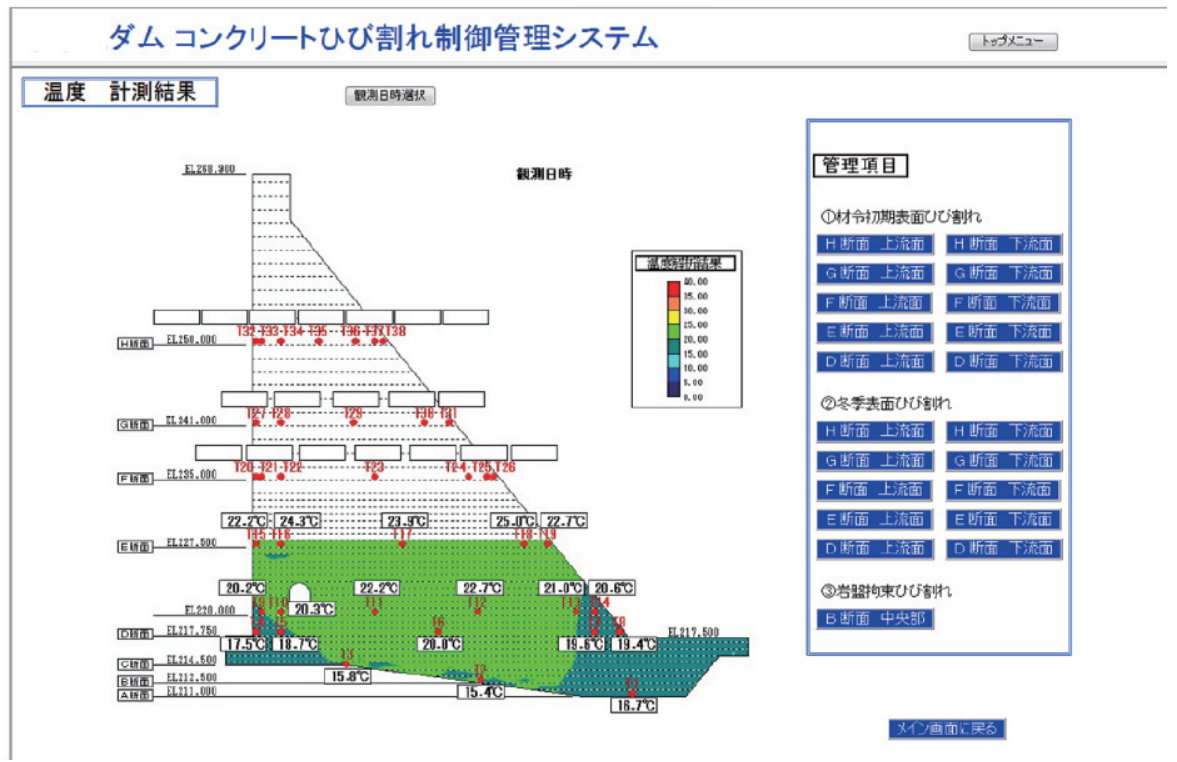

図-6 温度計測管理［温度計測結果］ 


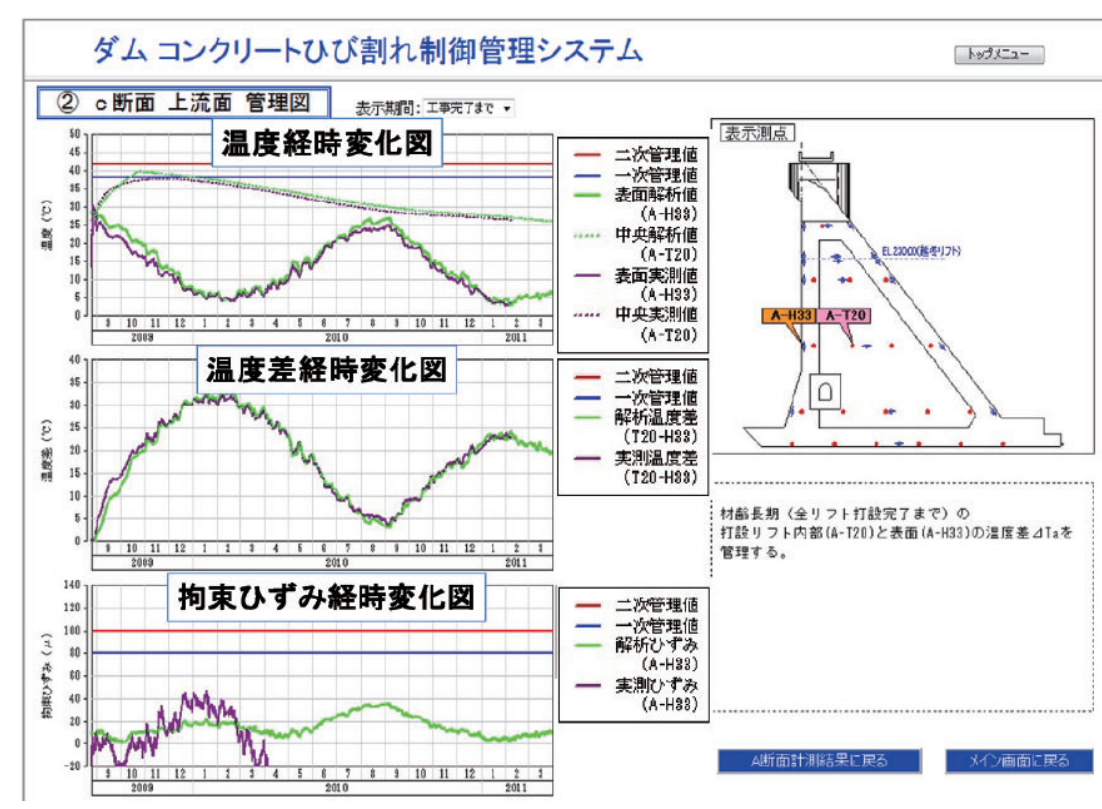

図-7 管理図の一例（内部拘束の場合）

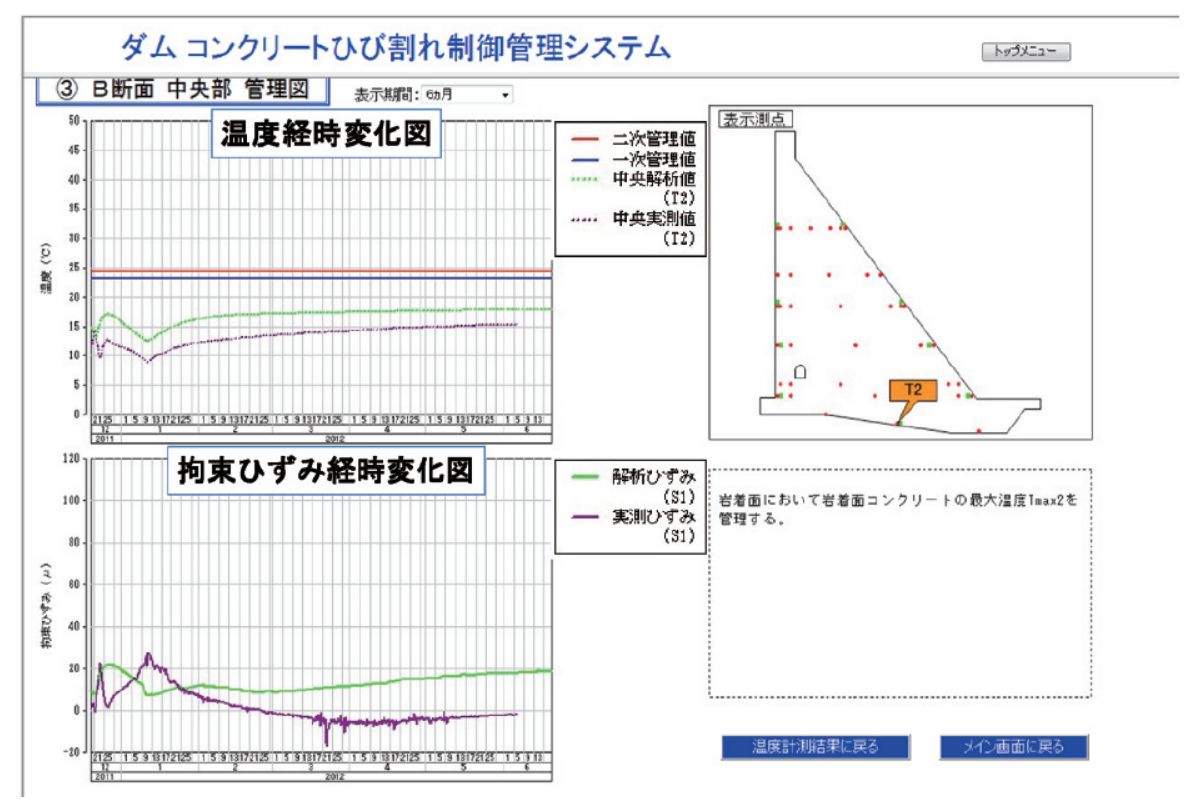

図-8 管理図の一例（外部拘束の場合）

管理図へ遷移できる仕組みである。

図-7に内部拘束ひび割れを対象とした管理図の一例 を，図-8に外部拘束ひび割れを対象とした管理図の一 例を示す。グラフ内には，実測值と合わせて，事前解析 結果と管理值も表示した。実施工では, 実測值と事前解 析結果が異なる場合は, 同定解析により管理值を再設定 しながら品質管理を行い，有害なひび割れを抑制した。

\section{6.おわりに}

コンクリートダム工事における品質管理情報の一元 化，データの信頼性や透明性の確保と，デー夕処理の効 率化を目的として，インターネットを使用した総合品質 管理システムを施工現場に導入した。本システムは,
2012 年 6 月時点で竣工済み 1 現場，運用中 3 現場の実 績がある。

ここでは，コンクリートの品質管理に特化したが，本 システムはフィルダムの盛土材料の品質管理にも応用 し，運用中である。

今後も, あらゆる工事現場への導入を行い, より効率 的な品質管理システムの構築に努めたい。

参考文献

1）大西隆雄 - 水口直仁 · 丸山敏男 - 西岡真帆：IT 技術を活用した高 流動コンクリートの品質管理, コンクリート工学, Vol.44, No.6, pp. $45 \sim 50,2006.6$

2）西岡真帆・江渡正満：携帯電話を活用したコンクリート施工管理 システム, 電力土木, No.340, pp.65〜68, 2009. 3 